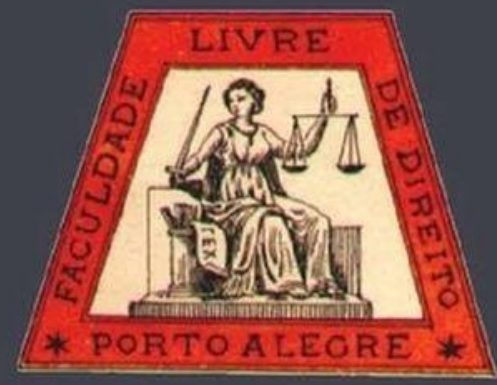

Middle class and public services in Brazil: commodity boom, economic crisis, and protests for a better public transportation system

Classe média e serviços públicos no Brasil: boom das commodities, crise econômica e protestos por um sistema de transporte público melhor

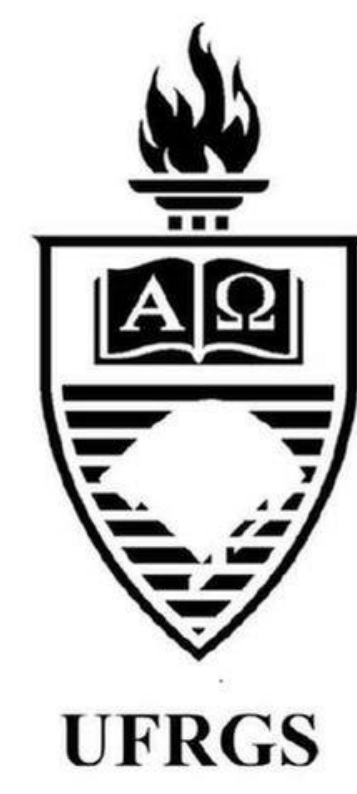

Andre Castro Carvalho

Massachusetts Institute of Technology 


\title{
Middle class and public services in Brazil: commodity boom, economic crisis, and protests for a better public transportation system
}

\author{
Classe média e serviços públicos no Brasil: boom das commodities, crise econômica e protestos por \\ um sistema de transporte público melhor
}

Andre Castro Carvalho*

\begin{abstract}
REFERÊNCIA
CARVALHO, Andre Castro. Middle class and public services in Brazil: commodity boom, economic crisis, and protests for a better public transportation system. Revista da Faculdade de Direito da UFRGS, Porto Alegre, n. 39, p. 109-133,
\end{abstract} dez. 2018.

\begin{abstract}
RESUMO
O objetivo deste trabalho é estudar o baixo nível atual de qualidade dos serviços públicos no Brasil, a fim de identificar uma relação entre a má qualidade de tais prestações e os protestos que vêm ocorrendo cada vez mais frequentemente no país. Entre outras demandas, alguns protestos foram inicialmente contra a baixa qualidade dos serviços prestados à população, especialmente o transporte público. Uma das principais razões para essa insatisfação é a recente ascensão da classe média nos países em desenvolvimento. Essa ascensão está aumentando a parcela de participação nos processos decisórios (a classe média representa cerca de metade da população brasileira), e esse engajamento está moldando novas demandas por políticas públicas mais voltadas para seus valores. A classe média tem um forte poder de consumo de bens e serviços privados: essa influência levou as empresas privadas a modelar seus produtos e serviços de acordo com suas preferências, mas os governos ainda estão oferecendo serviços de menor qualidade do que a classe média está disposta a receber. Esse descompasso leva a uma constante insatisfação pública e pode continuar a causar novas manifestações contra as atuais políticas públicas.
\end{abstract}

\section{PALAVRAS-CHAVE}

Serviços públicos. Manifestações e multidões. Classe média. Qualidade de vida. Países em desenvolvimento.

\section{ABSTRACT}

The purpose of this paper is to study the current low level of quality of public services in Brazil, in order to identify a relation between the bad quality of such provisions and the protests that have increasingly taken place in the country. Among other requests, some protests were initially against the low quality of services provided to population, especially public transportation. One main reason for this dissatisfaction is the recent rise of the middle class in developing countries. Such ascension is increasing their share of participation in the decision-making processes (the middle class represents roughly half of the population in Brazil), and this engagement is shaping new demands for public policies oriented more towards their values. The middle class has a strong power of consumption of goods and private services: this influence led private companies to model their products and services to their preferences, but governments are still delivering lower quality services than the middle class is willing to receive. This mismatch leads to constant public dissatisfaction and may continue to cause further riots against the running of current public policies.

\section{KEYWORDS}

Public utilities. Riots and mobs. Middle class. Quality of life. Developing countries.

\section{SUMÁRIO}

Introduction. 1. Historical background in Brazil. 2. The middle classes around the world. 2.1. The core values of the middle class. 2.2. Definition based on income. 3. The particularity of the middle classes in Brazil. 3.1. The governmental concept of middle class. 3.2. The demands of general middle class and the "opting out movement". 3.3. Standards: the dichotomy between "premium" and "low cost". 4. Rebellion for better public services in Brazil. 4.1. The purchasing

\footnotetext{
* Pós-doutor pelo Massachusetts Institute of Technology, com bolsa CAPES de Estágio Pós-doutoral no exterior (Proc. $\mathrm{n}^{\circ}$ 99999.007456/2015-08). Doutor, Mestre e Bacharel pela Universidade de São Paulo.
} 
power is not in line with the delivery of public services. 4.2. Protests led by youths and middle class. 4.3. The case of public transportation in Brazil. Conclusion. References.

\section{INTRODUCTION}

This research shall use specific references to middle classes and delivery of public services in the literature of Economics, Law, and Social Sciences in order to demonstrate the following idea: the rise of the middle class in developing countries, like Brazil, is shaping new demands for public policies related to public services. This hypothesis shall be developed by the analysis of some values that are intrinsically embedded by the middle class, which collide with the current level of services delivered by governments. This paper serves as a supplementary part of the results previously presented by Carvalho \& Contani (2015).

Brazil had huge and widespread protests across the country in June 2013. Initially the protests in June 2013 happened due to poor public transportation conditions; but later on, the demands were also for better health and education - and in particular against the expenditures for the FIFA World Cup 2014. The protests called for no more corruption in the government, and they were the main reason for the subsequent protests in 2015 and 2016 against the government of Dilma Rousseff.

Street protests also seem to be a trend in some newly developed states. Singapore recently experienced the same public dissent against increasing public transportation fares (The Wall Street Journal, 2014). The Malaysian middle class was also protesting due to the economic situation in the country, occupying streets that were previously the territory of student activists and poor workers (Time, 2015).
In Hong Kong, the middle class is active in public protests because they usually receive what they demand from the authorities. The movement of the young middle class occurred during the Umbrella Movement protests might be an example: the middle class as a whole saw the effectiveness of the protests (Bush III, 2014), as did the citizens of Singapore regarding public transportation.

This might be a sign that the pace of economic development in a nation should be in accordance with the development of its infrastructure and public services. On the contrary, economic development could reveal a future bottleneck in a country, which has a potential to slow down the pace of economic development.

There is a particularity in the Brazilian case: its current bottleneck is a consequence of the classic past models for delivering public services, which are centered on the cost, not on the quality provided to the citizen. We assume that if policies had been focused on the needs of the emerging middle class, the delivery of services could have been better and they could be more used by the population, reducing the high level of "opting out" to private services.

As a consequence, maybe the riots protesting the bad quality of public transportation (or any other public services that may have the same problem) would not have taken place. This is a critical aspect for Brazilian policy-makers: be more connected with the "new" Brazilian middle class, which represents - in the words of Berlin (2006) - the "common man of our century" - or the common man of "our" country. E. g., in India, 
the middle class claims itself as a representation of the citizens of the country - as the 'aam admi' (common man) (Taguchi, 2013).

\section{HISTORICAL BACKGROUND IN BRAZIL}

Jim Yong Kim (2014), President of the World Bank, highlights that "for the first time, the number of people in the middle class surpasses those living in poverty." This is a paramount change in our society, but we have not seen any institutional changes from governments to meet their demands. Moreover, most countries in the 20th century experienced growth accelerations that were not accompanied by significant changes in institutions or policies for the economy and politics in general (Hausmann, Pritchett \& Rodrik, 2004).

At the very same time, the subprime crisis happened in 2008 in the majority of developed countries in the world. The middle classes in the developed world, such as in the United States, is shrinking: they are not appropriating the same share of American growth as they were in the past (Burkhauser, Larrimore \& Simon, 2012). In fact, some argue that globalization brought to developed countries few changes in real income between 1988 and 2008 for those between the $75^{\text {th }}$ and $90^{\text {th }}$ percentiles of the global income distribution (Milanovic, 2012). This is very similar to what happened in the $19^{\text {th }}$ century, where the reductions in transportation costs led to a globalization process that has made the American middle class suspicious of the rising power of corporations (Zingales, 2015).

As a consequence, emerging countries, as China, India and Brazil, and its middle class were meant to be a "new hope" for the maintenance of the global economic development. The estimation is that this middle class of 2 billion people will reach 5 billion by 2030, and have a spending power of USD 20 billion by 2025 (Javalgi \& Grossman, 2016).

Alston et al. (2016, p. 24) argue that Brazil has initiated its transition to the developed world: "Brazil is well on the way to transitioning to a society whose hallmarks consist of four pillars: (1) powerful organizations in society agree to play by the rules (e.g., the constitution and other formal laws), (2) politics are competitive and transparent, (3) those in power and citizens have a strong preference for macroeconomic stability, and (4) economic outcomes should be 'fair'; that is, a critical role of the state is to assist inclusion through redistribution and quotas." We may notice these characteristics in Brazilian economic and political situation.

This transition, however, may be delayed due to the recent economic crisis in this decade. Although Brazil's economy "took off" in the past 10 years (The Economist, 2009) and "blew it" in five years (The Economist, 2013b), followed by its "fall" (The Economist, 2016), the strategy for economic development has been proven to be a failure in the long-term.

Brazil is commonly considered as a naturalresource-based economy and politicians are not usually very concerned about important institutional issues. The country did not carry out many of its necessary huge reforms in social security, health, education, infrastructure, bureaucracy and tax system - areas whose core has been the same since 1988 with the new Constitution. The political coalition system (presidencialismo de coalizão, or "coalitionbased presidential system") also created a hurdle for these necessary reforms. The pork-barrel politics created a "better" environment to support national projects, and because of that, these reforms were considered a secondary priority for the politicians.

Thus, the strategy adopted by the country was not sustainable enough to face the economic crisis brought in 2008. Overspending and lack of 
investment, especially in infrastructure, brought the country to one of its worst crisis in history in the middle of the 2010s. This was an outcome predicted by some sectors of media and professionals, as they did not anticipate Brazil as a real potential nation: Brazil's model was very different from the ones applied in China, India or South Korea, for example (Alston et al., 2016).

Limongi (2013), following the thoughts of Moore Jr. and in an evolution of his previous work with Przeworski, shows that "late comers" would need a different process of development in comparison with the "early comers" (mainly represented by the OECD countries).

On the other hand, China's recent massive investment in infrastructure and public services a standard movement of early comers in the past showed that, in order to foster their development, late comers have to be careful about the quality of their infrastructure and public services. For instance, Schuck (2014) demonstrates that various "policies successes" are related to better public services - such as the interstate highway system and the Airline Deregulation Act of 1978 in the United States. This explains why such policies have become the primary matter of concern for governments.

In this sense, we argue that Brazil should follow some of the policies of the Western developed countries for public services delivery, more focused on quality of what is delivered instead of low-cost services. Perhaps Brazil should be inspired by the past policies of early comers for its "late comer approach" - as China and India have.

\section{THE MIDDLE CLASSES AROUND THE WORLD}

\subsection{The core values of the Middle Class}

The middle class is allegedly a group with significant influence in world history. The middle-class individuals were an essential factor for the Industrial Revolution in England due to their long-term thinking that was disseminated through the British society. Most of their features, as we know nowadays, are resemblances to the values of the British post-Industrial middle class. The importance of this category for modern governments remains nowadays: a good representation is the Middle Class Task Force, a recent initiative from the Presidency of the United States (Tannenberg, 2014).

Some values are seen as a standard for middle class in developed states, such as individualism, meritocracy, rationalism, hard work, initiative and free enterprise: this is the idea that middle class is "people like us" in economic, social and geographical terms with a strong collective identity (Kravets \& Sandikci, 2014; Javalgi \& Grossman, 2016).

Deutsch, Silber and Yalonetzky (2014) stressed some characteristics that literature has brought about middle class over the years: (i) middle-aged people; (ii) educated; (iii) with small number of children; (iv) high spend in health care; (v) own their house; (vi) have one or two cars. These behaviors make them own an enormous amount of debt. Moreover, regarding their values, they (i) have entrepreneurial spirit; (ii) work in specific occupations; (iii) in stable jobs; (iv) believe in the democracy and tolerance; (v) are optimistic about the future, meaning that they can do better that their parents; (vi) are the 'engines' of economic growth.

It is noteworthy that these characteristics vary from developed and open market countries, like the United States and the United Kingdom, to emerging markets such as Brazil or China. Maybe entrepreneurial spirit might not be one of the values of Brazilian middle class - especially for the share who works for the public sector -, but many of the economic characteristics are very similar, and some values are becoming more disseminated in the Brazilian society. Alston et al. 
(2016, p. 217) mention an interesting study which demonstrates that the entrepreneurial spirit seems not to be a rule for the middle class in developing world: "Banerjee and Duflo (2008) provided an example of the disconnect (or long lag) between standard historical reasons given for the centrality of a large middle class for investment or innovation. They examined survey data from individuals in thirteen developing countries. Instead of finding the middle class a hotbed for entrepreneurial spirit, saving, and innovation, they found that the middle class mostly desires a well-paying job, often in the bureaucracy. Although this initially goes against the received wisdom of the importance of the middle class for growth and progress, it does not mean that the middle class is unimportant". As a popular saying in Brazil: "people usually are looking for a job, not work to do."

Political engagement is also a trait in middle-class groups. Their role is expected to be a mediator between rich and poor, especially regarding economic policies (Tannenberg, 2014). In countries where voting is not mandatory, it is said that the middle class has a channel of influence by its propensity to vote, especially when electing and influencing politicians (in a bottom-up approach) to be more careful with their demands on public services (Hastings et al., 2014).

In theory, considering that the middle class is more interested in politics than the poor classes, their members are more capable of translating their demands into political achievements. In Brazil, voting is mandatory: given that the spectrum of voters is larger, it is more complicated to them to be this bridge described above. However, in recent years, more top-down political activity has been noticed: as an illustration, there was recently a middle-class movement towards politics in Brazil with the creation of Partido Novo (New Party), a libertarian party composed basically of middle- class liberal professions and entrepreneur politicians. On the contrary, some of the new middle class and the younger are more organized around the Rede Sustentabilidade (Network Sustainability), a moderate left-wing party more concerned with environmental issues.

Some argue that the middle class is a Western idea sometimes not suitable to Eastern nations. In Russia, v. g, Samson \& Krasil'nikova (2014) states that the concept of the middle class does not help to understand the complexity of Russian society. Therefore, the middle-class ideal would be a 'myth' in that country.

However, Brazilian middle class is a reasonable standard for the world middle class, since, according to Neri (2011, p. 84), a Brazilian who has a middle income has $62 \%$ of the world population below him whereas the American who has a middle income has $94 \%$ of the world population below him. Based on the income, the Pew Research Center created an "income calculator" to compare if someone belongs to the global middle class (Pew Research Center, 2015).

Because the values of a standard middleclass person vary across countries and cultures, a definition based on income is meant to be more neutral around the world.

\subsection{Definition based on income}

One of the most objective definitions of the middle class is based on income, since it highlights the ability of this group to consume new products and services, and models the ideas and behaviors of this social stratum - concerning education, culture, environment, etc. This may create a "homogeneous set of social orientations" which may be called "middle-class consensus" (Josten, 2013). Teichman (2015) adds the need of an income considerably above of the lower class and an urban characteristic of the middle class, with several categories of professionals on it. 
An important factor of stabilization in the middle class is the likelihood of being paid on a monthly basis for their services, which is quite different from the poor classes that usually deal with casual payments. This fact makes them more vulnerable with respect to the existence of a steady source of income for their household expenses. This is a fundamental factor allowing a long-term thinking and planning for the middle class (Tannenberg, 2014), like education, housing, and retirement.

With the commodity boom, the middle class in Latin America has doubled since 2000, and the Asian middle class has increased sevenfold in the same period (The Economist, 2014). In Brazil, lower middle class expanded with the commodity boom and, with more access to cheap credit, they could access goods and services more related to upper middle class, like new cars and their own house.

This growing process is similar to what developed states experienced in the past: the rise of the middle class built a group of specific values which were responsible for designing policies along the history of the 19th and 20th centuries (Souza \& Lamounier, 2010), especially in the United States (Mills, 1966).

In Latin America, contrasting to this standard middle class group, there are the strugglers (Birdsall, Lustig \& Meyer, 2014), which means a group between the average threshold of US\$ 4.00 to US\$ 10.00 daily per capita (2005 PPP), far from the average threshold of US $\$ 40.00$ per day for a standard middle class home. We will see further that the official concept of Brazilian middle class is much closer to the strugglers (which indeed represents the lower middle class) than this idea of global middle class above the threshold of US\$10.00.

\section{THE PARTICULARITY OF THE MIDDLE CLASSES IN BRAZIL}

\subsection{The governmental concept of middle class}

There are several ways to measure who is in the Brazilian new middle class. Neri (2011), for example, uses a mix of the potential for consumption (as refrigerators or washing machines), generation of income and expectations for the future. A similar consideration is made by Salama (2014), where income and consumption are seen as criteria for defining middle class. But for public policies - which will require a more objective approach -, Brazilian agencies usually prefer the definition by income in their analysis.

According to the Secretary of Strategic Issues, the Brazilian new middle class or "Class C" is represented by families who earn approximately from US\$ 90 to US\$ 320 (exchange rate of US\$1.00 = R $\$ 3,20$ ) monthly per capita (SAE, 2013). This is the so-called "new" middle class, which is very similar to the concept of "strugglers" discussed before. As Neri (2011) says, it is different from the depreciative expression nouveau riche, since it has a prospective meaning about expectations and realizations. It is hard to define the key features of this middle class since it represents all groups that have crossed the line of poverty: for instance, agricultural workers, employees in urban centers and different familiar groups from young couples to the elders (SAE, 2013, p. 11).

Alston et al. (2016, p. 135, Figure 6.6) show how the economic pyramid changed since 1993 : at this time when Class $\mathrm{C}$ was about 45.6 million people, today is around 105.4 million people or almost half of the Brazilian population. Classes A \& B have also increased, whereas Class D \& E reduced from 92.9 million to 63.6 million. Their definition for Class $\mathrm{C}$ is a monthly household income in Reais, in July 2011, from R $\$ 1.734,00$ to $7.475,00$ - Neri $(2011$, p. 82, Table 3.1), on the other hand, uses a lower range, from $\mathrm{R} \$ 1.200,00$ to $\mathrm{R} \$ 5.174,00$. Both classifications are much 
more realistic than the one created by SAE and both of them capture a better picture of Class $\mathrm{C}$.

With an abundant line of credit provided by banks and local financial institutions, the new middle class begins to have access to all products and services that were previously provided to the "old" middle class, such as credit for buying cars, appliances, smartphones, flight tickets and a first house. The result of easy access to credit is that reaching the middle tier is strongly related to the household consumption (Bello, Mascarello \& Keller, 2014).

Income is the element that has defined this new group as middle class. The other shared values of the middle class have not emerged very clearly during the rise of Class $\mathrm{C}$. As a result, the "old" middle class in Brazil continued to be represented by private entrepreneurs, high-skilled professionals and public employees - very similar, to some extent, to the upper middle class in China (Goodman, 2014).

Neri (2011) states that credit and entitlements have supporting roles, but the true protagonist in the lives of people in this group is formal employment, either in the private or public sector. Small businesses appear as a secondary characteristic in this group due to enormous difficulties for entrepreneurship, such as extensive red tape and an intricate tax system Brazil is in the $75^{\text {th }}$ position (of 140 nations) in the Global Competitiveness Index of 2015-2016 (World Economic Forum, 2016).

An interesting aspect of the Brazilian population is that, according to the Gallup World Poll, people individually perceive their lives as better than the lives of the Brazilians as a group. This means that most of the problems are not individual - such as in purchasing power. However, people are upset with their collective goods: public safety, education, health, etc. This is why Neri (2011, p. 44) says that "the problem of Brazil is more of the whole Brazil than that each Brazilian.”

\subsection{The demands of general middle class and the "opting out movement"}

The current importance of income and power of consumption is making the "new" and "old" middle class equal in the market in an economic sense. In the same way, citizens may be in better conditions to determine the level of public services they want back from the government - this is what Osborne \& Gaebler (1992) call empower the consumer by giving him the option to choose what she or he prefers (a consumer-driven government).

But the fact of being a significant consumer in a market society, which is shaping a new developmental state, is not aligned with how the Brazilian government has been considering the people in this position. Instead of viewing them as citizens from an emerging and developing country, Brazil still has public services with the status of an underdeveloped one. It means that the concept of middle class is being restricted to the market approach (i. e., consumption) since the domestic consumption has been one of the strategies in Brazil and Latin America to foster economic growth (Milanez \& Santos, 2015). However, with respect to the public interest, this new class continues to be treated by the government as it always was before: as a poor class.

This lack of consideration with the delivery of public assets and services may limit public policies: any attempts to enlarge the fiscal burden of the riches in order to deliver better public services for the middle class (Piketty, 2014) could be denied by the society as a whole - especially in Brazil, the worst country in the world on returning taxes to taxpayers in form of public services (G1, 2015). This poor relation between taxpayers' money and public services leads to a massive "opt out" for private services instead of more pressure for the improvement of the services delivered by 
the government. Usually, members of the middle class prefer an opting out option instead of protesting or expressing public dissatisfaction to require improvement of services for the population. It is particularly interesting when we see a substantial growth of the idea that government should take more responsibility to provide welfare to its citizens in the country, according to the results of World Value Survey from 1989-1993 and 2010-2014 (Alston et al., 2016, p. 31, figure 2.2).

The quality of public services impacts both rich and poor: the former because they opt out and have to pay twice for the services (the public ones they do not use and their private solutions); the latter because they will not value them as a proper delivery of public services (Sánchez \& Senderowitsch, 2012). This is the reason why the new middle class also started to opt out for private services; services with a lower quality than that sought by the old middle class, but still with more quality than public services. Better health insurance (opting out from Sistema Único de Saúde - SUS), private elementary and high schools for their children, and cars and motorcycles instead of public transportation are symbols of this movement towards private services.

Typically, for a member of the Latin American middle class, when their incomes rise, they start to opt out to private services, especially for their children. Such phenomenon happens very clearly in the Dominican middle class, where they have opted out to individualized solutions such as "heavy reliance on domestic generation of electricity, the digging of wells to get running water at home, the use of private companies to report car accidents (instead of doing it at the police station), and the use of private services for education and health" (Sánchez \& Senderowitsch, 2012, p. 2).

With their demands for better services, the influence of the middle class is substantial in shaping the quality of public services in areas such as sanitation, telecommunications, and public safety. Concerning education, on the other hand, individuals prefer to use private services (especially for their children), which leads to less popular pressure on the quality of such public services as well as the opting-out movement to private schools. These private schools usually perform better than the country's score at the Programme for International Student Assessment (PISA). Accordingly, the importance of the middle class regarding the designing of public policies for all services is noteworthy.

Some argue that one of the potential causes of the low quality in public services such as education and health is the absence of middleclass members using them since they opt for private services - to the extent that the poor and strugglers do not value the services according to their cost due to the low quality. This opting out could alleviate the political pressure from the middle class for a better quality of such services (Birdsall, Lustig \& Meyer, 2014). In this sense, some politicians believe that the middle class should come back to the public schooling system as they were users in the 1970s (UOL, 2014).

The lack of importance given to public services by the government causes a general public dissatisfaction, especially with the current rise of income of the Brazilian middle class. The main reason for unhappiness is because the general middle class is very concerned about the quality of the provision of such services: people do not accept anymore the concept of "cheap and bad" - some scholars even argue that there is a bias for "low price" in Brazil, which may lead to a Latin American concept of "low-cost society" (Franco, Hopenhayn \& León, 2011). After the FIFA World Cup 2014, critics ironically stated that Brazil has some services "FIFA standard," such as arena stadiums or the airport of Brasília, and other services "Brazilian standard," 
such as public transportation, sanitation, or education.

This was the context in which the presidential elections took place in 2014: the consumption standards were not equivalent to the public services standards because people were asking for more quality, not just quantity. But, according to Unger (2014), without economic growth, it becomes complicated to provide reasonable public services; without open access to public services it becomes hard to have economic growth. Based on this assumption, the main presidential candidates of 2014 election (Dilma Rousseff and Aécio Neves) should have addressed this issue during their campaigns. But none of them were capable of presenting a solution to the problem and the imminent crisis that Brazil was about to cope with.

\subsection{Standards: the dichotomy between "premium" and "low cost"}

In comparison with all public services provided around the country, it may be said that Brazil has few premium (and expensive) public services, comparable to the "European standards" - such as highways in São Paulo with expensive tolls (Folha de São Paulo, 2016) and reasonable telecommunication systems, having one of the most expensive mobile rates in the world $(\mathrm{O}$ Estado de São Paulo, 2014). But the country has many more low-cost public services - especially those offered to the poor citizens, like health, education, and public transportation. In other words, "wealthier households not only consume more but also want different goods, and with sustained growth, consumption patterns in middle-income countries are bound to become closer to those of the rich developed world" (Ferreira et al., 2013, p. 160). Indeed, much of the growth rate in cars or smartphones sales is due to the reduction of the cost of production and especially the creation of low-cost products for the general public (Salama, 2014).

What Brazil and Latin America need is a genuine process of "premiumization" of the infrastructure and public services delivered to their citizens. The problem is how to conjugate the need to raise prices with the compromises of affordability to the society. This is, for example, a current preoccupation in Vietnam (The Economist, 2013a). To get this improvement, we need to consider a cost-benefit analysis in which expensive services (those that require a fee payment) include poor and strugglers and not only the upper middle class.

For services with wide coverage and where there are no direct charges to the people, the best way to improve their quality is a reasonable tax system in which the richer are responsible for the greater share of their cost. This should be the case for health and education - the complicated tax system attempts to adjust the fairness share though the ability-to-pay taxation principle in Brazilian Federal Constitution. It states that "[w]henever possible, taxes shall have an individual character and shall be graded according to the economic capacity of the taxpayer [...]" (article 145, $\S 1^{\circ}$ ).

For more specific services with direct charges based on a fee (take the example of public transportation), some arrangements could be made: they should use a cost-benefit analysis together with the ability-to-pay taxation principle in order to balance their financing requirements. Membership programs that prioritize lower fees for frequent users (like the local population who lives in the city) and charge the non-frequent users more, like tourists, could be an option. This is what cities like New York do when they charge, proportionately, more for the single ride or weekly tickets than monthly tickets holders. What must be avoided is the "illusion of gratuity" where population fights to have non-fee services instead of searching for ways of charging more a 
particular group of people who could afford to finance them in a more egalitarian manner.

These arrangements are especially important since the beginning of the Brazilian crisis in 2014. The Brazilian middle class is facing what Torche \& Lopez-Calva (2013) call vulnerability, i. e., the probability of middle class moving towards poverty in a context of economic instability. With the economic crisis since 2014, the number of households who had been considered middle class before and that are now "strugglers" has increased, especially with the combination of high inflation and out of control debt in the middle class, leading to an adjustment in consumption (O Globo, 2015). This means that they do not have enough means (asset/income/education) to have a complete protection against a downgrade in their position. This movement suggests that perhaps the "middle-income trap" is happening right now in Brazil.

Notwithstanding this fact, there is a change underway. In the developed world, the main demands of the middle class are changing from a collective perspective (like public services) to an individual standpoint. One factor of this change could be the technology development: it is responsible not only for spreading new ideas but also for delivering a better condition of life to individuals. The consequence is that people might be satisfied with the possibilities of technology (such as smartphones, digital TV, social media, etc.) more than with more money in their pockets. Therefore, the middle class would be comparatively better off nowadays than in the past - even if we consider that they will not recover the financial status they had during the post-war period (Washington Post, 2014; 2015).

That is the current reality in the United States, and it is very similar to the Brazilian context, especially after the commodity boom of the 2000s. Internet users and mobile phone holders have expanded to unprecedented levels in the country. In 2000, internet users in Brazil were about 2.9 users per 100 people; in 2014, they were 57.6 per 100 , very close to the statistics in the United States for 2000 (43.1 per 100). Mobile subscriptions followed the same trend: in 2000, there were 13 per 100; in 2014, 139 per 100. (World Bank, 2016)

The U.S. context is, however, different from the Brazilian one because most of the collective demands are reasonably provided by the state to citizens. A very different situation is seen in Brazil, where collective needs are surpassing the private demands as the primary matter of concern of people. Even though the economic crisis is a key element of mobilization of the masses, the bad quality of public services, aligned with more interaction and connectivity of people in Brazil (especially from the youth from this new middle class), led to the organization of public demonstrations against the public transportation system in 2013 and later, more specifically, yearning for an improvement of the quality of transportation, health and education in the country.

\section{REBELLION FOR BETTER PUBLIC SERVICES IN BRAZIL}

\subsection{The purchasing power is not in line with the delivery of public services}

The peculiarity of the collective demands of the Brazilian middle class is that people have achieved a strong purchasing power in the market (consumption) in the last decade, but they have realized that there are no public services offered by the government with the same standard of quality. When there is something like a "European" or "American" standard, such as turnpikes, the charges are very expensive for the average middle-class individual.

As discussed before, the current common sense says that "everything is all right inside our 
homes, but when we go outside, everything goes wrong": in other words, nothing works the way it is supposed to when Brazilians use public services. With the economic crisis since 2014, the emerging sector, frustrated with the quality of public services, also have been frustrated with the economic situation. So the Class $\mathrm{C}$, which was an active consumer of private products but an intensive user of public services, faced the problems both "inside" (purchasing power) and "outside" (public services) their "home" (Couto, 2015).

Something similar happens in the spatial distinction in India with the ghare/baire (inside/outside), the contrast between private and public space. In the private realm, things are clean, safe, and work well; the outside, in contrast, is a dangerous and negative place. This disorder prevents the Indian middle class from occupying public spaces (Taguchi, 2013).

There is a point of tension between the ideas of living well (what the government says to the citizen as a new public policy) and living better (what the middle class really wants). The Bolivian government argues for the application of the philosophy vivir bien (living well): people should seek to live in harmony with others, with no exploitation of the market, aiming for the common welfare. On the other hand, the application of the philosophy vivir mejor (living better), based on the improvement of the conditions of society focused on the individual, is not intended to be a public policy (MRE, 2010).

As a public policy, this line of thought contrasts with the way that early comers reached a development status (Chang, 2004), which shows that late comers like Brazil, Bolivia, Venezuela, Ecuador, Uruguay, and Argentina are not aligned with such ideas, perhaps as a countermeasure to the Washington Consensus (Stiglitz, 2006). However, it seems that the middle class prefers a more "living better" concept, especially since
2013 with the public protests that have taken place in the country.

\subsection{Protests led by youths and middle class}

During this decade, the developing and developed countries have in common some major protests that shaped the relations inside the respective countries' boundaries. Civil uprisings such as Occupy Wall Street, Occupy Davos, Movimiento 15-M, Arab Spring, Euromaidan, the Umbrella Movement, and the Brazilian protests of 2013 were made possible partially due to the connectivity brought by mobile phones and Internet, which facilitates the coordination of these public gatherings against/for a government, a cause or an idea. The flow of information leads to more and more people engaged in the cause according to the course of the events. It seems that the world is experiencing what Thaler \& Sunstein (2008) called "following the herd": the concept that social influence from groups is shaping the ideas and actions of individuals.

South Africa has been considered as the "protest capital in the world," and several protests over the delivery of services have taken place in the country in this century. As an example, there were massive protests against the privatization of municipal services in Johannesburg. Most of these protests, according to data collected in small towns in Western Cape and Cape Town, have led to the suggestion that participation by the middle class was higher than that of other classes (Seekings \& Nattrass, 2015).

Therefore, besides the connectivity, there is another characteristic in these recent public gatherings in both the developed and the developing world: they are organized by young people, usually from the middle class. In the Brazilian context, this is entirely different from protests from twenty to thirty years ago, when unions, parties or associations were the major players in public gatherings against or for an idea. 
It is important to underscore a difference between these labor demands of the late $20^{\text {th }}$ century in contrast with those street movements for more rights or better services: "[c]rucially, urban protests entailed claims on the state, often articulated in terms of rights. In this they contrast with workplace strugglers" (Seekings \& Nattrass, 2015). This happens, as Seekings \& Nattrass explain, because workers have a more specific demand for their employers - instead of what happens to the government when people demand better public services.

In a "winner-take-all-society," the leadership of such protests by young middle class citizens seems a signal that people are losing hope of changing the system from the inside and they are trying to search for an outside solution, and sometimes is not quite clear what they are fighting for and who they are protesting against (Zingales, 2015).

Birdsall, Lustig \& Meyer (2014) uphold the idea that the middle class plays a crucial role in politics for social policies in order to (a) minimize instability, (b) grow the economic pie, and (c) manage the public services well. As a consequence, the middle class should ally itself with strugglers in order to pursue these objectives; otherwise, a rise in populist spending may occur. Therefore, the old and new middle classes should not rely exclusively on the strugglers to pressure the government for a better quality of public services, while the members of the middle class keep opting out to private services. They should act together to achieve a common objective. The political influence of the middle class may vary according to the political weakness in other classes, such as the working class in nonEuropean countries (Teichman, 2015), which suggests that this is a favorable time for a leadership of the middle class in this process.

With the connectivity brought in by social media and the Internet, this "conversation" between two tiers may be easier than years ago, when unions or associations were responsible for this tas, and sometimes there was a stronger negative bias from the upper middle class against those organizations.

The behavior of middle class also may change due to the impact of redistribution ideas in each context: in authoritarian realities, the middle class is more prone to demands for democratization if redistribution is a relevant idea; otherwise, they may ally themselves with the dominant forces if they fear a downgrade in their conditions, which may undermine the redistribution progress (Teichman, 2015). This may have a political impact, as Neri (2011) underscores the relevance of Class $\mathrm{C}$ in the political process, since it could be responsible for deciding a presidential election.

This is why the traditional "old" middle class should ally themselves with the strugglers and the new middle class. If they distance themselves, it will be easier for populist political groups to grasp the power with a segregation discourse, like "us against them." Furthermore, the establishment of a link between the middle class and the richer groups will be more likely to happen, and this fact will put the new middle class and strugglers against the old middle class. Zingales (2015) states that, in general, populism is on the rise when people believe that they are losing economic rights.

So we consider public transportation to be an important "bridge" between strugglers and middle class, especially because the latter are casual users of this service. In this sense, the protests in 2013 allowed a unique proximity of these two classes, together with the youths, in a way similar to what happened in 1992 with the impeachment of President Collor de Mello.

\subsection{The case of public transportation in Brazil}

Augusto de la Torre, from World Bank Latin America, is skeptical about the rise of 
middle class and their role in shaping the quality of public services since their purchasing power is growing faster than the quality of such services. The protests held in Brazil against Dilma Rousseff were a demonstration of an important issue regarding this topic: in his words, "[i]t's a chicken-and-egg problem: will the middle class stay in the social contract and force the state to improve public services? Or, will the state improve public services and encourage the future middle class to stay public?" (Latin Trade, 2015)

What we can see in the realm of public transportation in Brazil is only the "chicken" side of the story: the middle class is trying to force the state to improve this public services. As discussed above, there is a tradition of opting out from public services by the traditional middle class, and it seems that is not a viable solution for the people if they keep waiting for the state to improve this kind of public service. Accordingly, the most likely scenario is the pressure that these groups might impose in order to shape the quality of public services in Brazil.

Some scholars argue that the middle classes usually organize themselves into groups - more often than the poorer classes, for example -, especially the more influential ones, in order to achieve their goals. This would lead to collective actions towards public policies (Matthews \& Hastings, 2013). In Brazil, it may be only partially true due to the engagement of the poor and the lower middle class in social movements, in particular through organized groups such as unions or political parties.

In the last few years, people from middle class have been organizing themselves in groups with some specific purpose. For the public transportation, the Movimento Passe Livre (MPL) - in English, the "Free Fare Movement" is the best example of a group that advocates for no fee charges in the municipal public transportation system. Other groups with different purposes have also been created through social media, such as the Movimento Brasil Livre (MBL) - in English, "Free Brazil Movement" -, a group of high school students of middle class against the government of Dilma Rousseff - and the leading group responsible for the protests during its second term in 2014-2016, together with an analogous movement called Vem Pra Rua (in English, "Come to the Streets").

Alston et al. (2016, p. 209) make an interesting link between the booing of the President Dilma Rousseff in the inaugural match of the 2013 Confederations Cup, on June 15, 2013, and the massive protests that started in Rio and São Paulo two days later together with the almost 1.4 million people on the streets on June 20. This had been a new trend for a country that had not had a tradition of massive street protests since Diretas Já in 1984 and the impeachment of Fernando Collor in 1992. Social movements in the country reached a historic mark on March 13, 2016, when Brazil had the largest protest in its history, with 3.6 million people on the streets (excluding Rio de Janeiro) against the government of Dilma Rousseff $(\mathrm{G} 1,2016)$

The protests in 2013 had a high participation rate of poor and middle classes, whereas the ones against Dilma Rousseff were said to be more concentrated by the middle class. In fact, the protests of 2013 already had a substantial participation of middle class: "Furthermore, the protests had a distinctly middle-class flavor with much communication over social media, similar to the Arab Spring and Occupy Wall Street movements. The coordinative capacity of social media played a role, and some analysts predicted that a new form of social participation had emerged in Brazil. Like the Arab Spring and Occupy Wall Street, the participation lacked leadership or a focal point of protest." (Alston et al., 2016, p. 210).

Thus, it is interesting to understand why public transportation worked as a catalyst for 
these public dissatisfactions. One reason we can speculate is that it is becoming hard for the middle class, especially the younger people, to opt out from public transportation in large cities such as São Paulo and Rio. As a result, both the poor and the middle class (especially the Class $\mathrm{C}$ ) were exerting pressure on the supply of public transportation.

In Brazil, especially in its largest city, São Paulo, some argue that the "middle-class automobile-oriented behavior" from the late $60 \mathrm{~s}$ has shaped the policies from public towards private transportation, which created a "middleclass city" that forces the poor people to use precarious public transportation. The consequence is that the cost of private transportation (construction of bridges, streets, tunnels, and other infrastructures) is "socialized" to everybody to the detriment of its use for few privileged ones (Vasconcellos, 1997). Moreover, "[a]side from the fact that most trips taken in cities are by pedestrians on foot, the transportation system in urban Brazil is basically bimodal private autos and municipal buses with growth of the former rapidly exceeding that of the latter" (Amann, 2016, p. 69). But this context has changed with the rising of Class $\mathrm{C}$, especially the younger people, who - as users - started to impose more pressure on more provision of public transportation (and more quality as well).

The Brazilian Institute for Applied Economic Research (IPEA) showed that cars are the preference when the educational level is higher, but in the richest Southeast region of Brazil, public transportation, as a percentage of transportation, is much more utilized than cars and motorcycles - more than $50.7 \%$ for public transportation against $37.2 \%$ for cars and motorcycles (IPEA, 2011, Figure 1, Graphic 1). This means that a considerable share of the Southeastern middle class is using public transportation - so their requests for better transportation services are a natural consequence of this fact.

As we stated before, a common movement of opting out occurs in public transportation: the central symbol of the success of the middle class is the ownership of a car or a motorcycle (or the service of a taxi) in order to avoid the uncomfortable public transportation. But due to the high costs around using a car in cities like São Paulo or Rio (high parking fees, gas prices, car insurance etc.), many people of the new middle class - especially high school, graduate students and young adult workers - prefer to use public transportation for work and private transportation for leisure on the weekends. IPEA (2011, Table 7) demonstrates that the two main reasons for a choice in transportation is quickness (32.7) and price $(14.8 \%)$. Thus, the cost is an important factor in people's decision on how they will move across the city.

But, in contrast, governors have thought that more investment in private transportation was needed, and there have been very few investments in public transportation in the city. Perhaps the last major reform of the system was the expansion of bus corridors and the introduction of bilhete único, a rechargeable card for buses, which was further incorporated with the state trains (CPTM) and subway system (Metrô).

Public transportation has then become a battle for the poor and the low middle class who are dependent on the service: too much demand not met by the supply. The quality of the service is a common complaint from users - a recent survey on Moovit, a mobile app, shows that public transportation in Brazil is crowded (1.3 on a scale from 0 to 5.0), dirty (1.3), running constantly late (2.7), uncomfortable in temperature (2.5), but with fairly good drivers (4.5) (Veja, 2016). The actual price ( $\mathrm{R} \$ 3,80$, or around USD 1.15), although not expensive comparable to developed cities, is much higher than other large cities located in Latin American developing countries, 
like Mexico City (from USD 0.19 to 0.25 ) or Buenos Aires (USD 0.30).

As mentioned before, protests in Brazil had been commonly organized by groups like unions, associations, or political parties. But in June 2013, the protesters were firstly coordinated by MPL with its decentralized structure and primarily relying upon social networks on the Internet. The justification was the increase in the fee of $6.7 \%$ (from $\mathrm{R} \$ 3,00$ to $\mathrm{R} \$ 3,20$, around USD 1.50 at that time), a very similar rate to the inflation rate of the period.

But, at that time, the economy was not booming as before, and the cost of transportation was having a considerable impact on Brazilian household budgets. The year 2013 was the last year that Brazil experienced significant growth from the commodity boom - the GDP growth was quite reasonable at that time $(2.5 \%$ according to the World Bank). In the following years, the country faced one of its worst recessions in modern history.

Public transportation has also been costly in some developed countries. In the United States, it is noteworthy to mention the weight of this category in the expenditures by households, whose costs rise precisely in the middle-class tier according to the share of their income (U. S. Department of Labor, BLS, 2015, Chart 1). Moreover, the United States also face a challenge regarding the quality of their public transportation: $42 \%$ of the bus systems and $26 \%$ of the rails are in marginal or poor condition (Federal Transit Administration, 2010). And "Americans who are lower-income, black or Hispanic, immigrants or under 50 are especially likely to use public transportation on a regular basis", with $33 \%$ of U.S. adults below 50 years old using public transportation on a daily, almost daily or weekly basis (Pew Research Center, 2016). Therefore, there are some similarities with the Brazilian public transportation system: not in good condition, considerably expensive for the lower middle class, and having young people as the most frequent users.

In São Paulo, Rio de Janeiro, and other Brazilian cities, although it was not the only cause of public dissatisfaction with the government at that time, the rise in bus fares in 2013 somehow triggered the protests. Alston et al. (2016, p. 213) argue that the protestors could not detect the improvements in the economy and the social inclusion which happened in the previous years because some dissipations occurred in Rousseff's government, like strong state intervention and creative accounting in public finance.

As we discussed before, the social achievements in the country were focused on the purchasing power of people, and they had not been focused on the improvement of public services such as health, education or public transportation. The moment that the looming economic crisis threatened their purchasing power - and the transportation costs had a considerable impact on household income -, people from the middle class realized that their social achievements were basically in the private realm.

The quality of public services, for the most part, remained the same over the past decade, with no improvements during the "commodity boom years," and the people could not simply accept such rise in the bus fare without any improvement in the transportation system. Moreover, not only public transportation but everything in the country (health, education, public safety, infrastructure, and a corrupt political system) had been delivered in a very similar way at that time compared to a decade ago, despite the economic boom. These massive public protests were a consequence of a rare moment of collective insight, which has united strugglers and middle class in a unique way for an old and known agenda: the improvement of the living conditions of every Brazilian in a collective sense, regardless of her/his economic class. 


\section{CONCLUSION}

As stated by Stiglitz (2006), it seems that the economic globalization has happened faster than political globalization: this means that the focus may be on the improvement of public policies towards a better quality of life, and not only in the concern about the increase of GDP. This hard choice is the current dilemma faced by the people in Brazil.

After a severe economic crisis, a sort of adaptation is needed by the population. Expenditure must be controlled as the revenues are not abundant anymore. The Brazilian population - as well as the Brazilian government in federal, state and local level - is following the steps of the European consumers in 2008: adapting their costs in order to avoid the loss of the new good standard of living from the last years (Exame, 2015). Cutting expenses is never an easy task, especially when some adaptation in the way of living is required. But essentially is a process where people want/need to maintain their quality of life with fewer resources.

The shift in their behavior should be taken into consideration regarding public services. Politicians should be aware of this new context in their decision-making processes for public transportation, especially when some change in the fares is required by public agreement provisions. Applied to the economic in public utilities, Grout, Jenkins \& Zalewska (2014) notice a recent trend in the United Kingdom regarding the theory of regulatory capture in comparison with historic cases held in the Supreme Court of the United States (Smith $v$ Ames 169 US 466,1898): instead of attending to the interests of the industry, the behavior of regulators has been prioritizing short-term consumer or user interests. This means that they are harsher with the companies regulated and politicians could be a beneficiary of this behavior in their decisionmaking process.

In fact, people from the Brazilian middle class realized that "market consumption" is not equivalent to "public services consumption" in their country. And they learned it in the worst possible context: within a severe economic crisis. At this moment, the focus should be the improvement of public services, because more people will start to demand it in an environment of crisis. Not only public transportation but health and education will probably suffer a positive demand shock.

The judicial system may provide a way to pressure local governments for a better quality of public services. Therefore, people should not rely exclusively upon public protests on the streets. For instance, there has been a growing active interference of the Judiciary in the provision of public transportation in Brazil.

Users should be conscious about the possibility of filing lawsuits against local, state, and federal governments in a way they can force, through legal measures, the improvement in the delivery of public services. Recently, the Brazilian Supreme Court (Supremo Tribunal Federal, case SL 805) ruled a decision in order to sustain a court decision in the São Paulo State Court (which confirmed a previous ruling of the local court of Miracatu, a small city in the state of São Paulo). The Municipality of Miracatu was using school buses to deliver public transportation to the local population - instead of using adequate buses from regular lines. According to the decision ruled against the Municipality, Miracatu had to stop using school buses and provide adequate public transportation to people until a public bidding for the service could take place.

In another recent case in the Superior Court of Justice (Superior Tribunal de Justiça - STJ, case AgREsp 905.551), the São Paulo Metropolitan Train Company (CPTM) was required to pay punitive damages in order to 
compensate the plaintiff - who was a lawyer and a frequent user of the public transportation system - for pain and suffering caused by CPTM. STJ found that the company caused this pain and suffering via the poor treatment of passengers during rush hour: the court agreed with the plaintiff that the employees pushed the passengers into an overcrowded car "as they were animals." This situation was recorded with a mobile phone, whose recording was subsequently offered into evidence by the plaintiff. He argued that the users pay a fare with a legitimate expectation that the company will avoid this overcrowding condition, which seems not to be the case.

This means that the battle for better public services should not only be concentrated on the streets, but also in an institutional way, both through the executive and judiciary branches. The Brazilian institutions were put to some tests in a recent couple of years with a traumatic impeachment process and the overwhelming Operation "Car Wash" against corruption. Considering that transparency and independence were values assured throughout these episodes, the effectiveness of the institutions has apparently been proved. Therefore, this is an excellent window of opportunity to use such institutions for the improvement of the public services in the country.

\section{REFERÊNCIAS}

ALSTON, L.; MELO, M.; MUELLER, B.; PEREIRA, C. Brazil in transition: beliefs, leadership, and institutional change. Princeton: Princeton University Press, 2016.

AMANN, E. et al. Infrastructure and its role in Brazil's development process. The Quarterly Review of Economics and Finance, v. 62, p. 66-73, 2016.

BELLO, E.; MASCARELLO, R. P.; KELLER, R. J. Brazil's 'new middle class' and the effectiveness of social rights through consumption: a dialectic of inclusion and exclusion. Birkbeck Law Review, $\mathrm{v}$. 2, n. 1, p. 129-145, 2014.

BIRDSALL, N.; LUSTIG, N.; MEYER, C. The Strugglers: the new poor in Latin America? World Development, v. 60, p. 132-146, 2014.

BERLIN, I. Political Ideas in the Romantic Age: their rise and influence on modern thought. HARDY, H. (Ed.); CHERNISS, J. (introduction). New Jersey, Princeton University Press, 2006.

BOLIVIA. Ministerio de Relaciones Exteriores - MRE. Vivir bien. Disponível em: <http://www.cancilleria.bo/sites/default/files/libros/vivir\%20bien.pdf>.

BRAZIL. SAE - Secretary of Strategic Issues. Comissão para a definição de classe média no Brasil. 2013. Disponível em: <http://www.sae.gov.br/site/wp-content/uploads/Relat\%C3\%B3rioDefini\%C3\%A7\%C3\%A3o-da-Classe-M\%C3\%A9dia-no-Brasil1.pdf>. 
BURKHAUSER, R. V.; LARRIMORE, J.; SIMON, K. I. (2012) A 'second opinion' on the economic health of the American middle class. National Tax Journal, v. 65, n. 1, 7-32, 2012.

BUSH III, R. C. The roots of Hong Kong Protest. Brookings Institution, Sept. 30, 2014. Disponível em: <http://www.brookings.edu/blogs/up-front/posts/2014/09/30-roots-of-hong-kong-protest-bush>.

CARVALHO, A. C.; CONTANI, E. Perspectivas na prestação dos serviços públicos de transporte na América Latina. IGLESIAS, E. (Ed.). Os desafios da América Latina no Século XXI. São Paulo, EDUSP, 2015.

CHANG, H. Kicking away the ladder: development strategy in historical perspective. London, Anthem, 2002.

COUTO, C. G. O PT na conjuntura política brasileira. O Estado de São Paulo. May 4, 2015. Disponível em: <http://politica.estadao.com.br/blogs/gestao-politica-e-sociedade/o-pt-na-conjunturapolitica-brasileira/>.

DEUTSCH, J.; SILBER, J.; YALONETZKY, G. On bi-polarization and the middle class in Latin America: a look at the first decade of the twenty-first century. Review of Income and Wealth, series 60, supplement issue, nov. 2014.

EXAME. Brasileiro corta básico para manter supérfluo, diz estudo, jul. 20, 2015. Disponível em: http://exame.abril.com.br/economia/noticias/brasileiro-corta-basico-para-manter-superfluo-dizestudo>.

FEDERAL Transit Administration. National State of Good Repair Assessment. June. Disponível em: <https://www.transit.dot.gov/sites/fta.dot.gov/files/docs/National_SGR_Study_072010\%282\%29_0.p $\mathrm{df}>$.

FERREIRA, F. H. G. et al. Economic mobility and the rise of the Latin American middle class. Washington: World Bank, 2013.

FOLHA DE SÃO PAULO. Conheça a melhor rodovia do Brasil, com asfalto ecológico e altos pedágios, july 16, 2016. Disponível em: <http://www1.folha.uol.com.br/mercado/2015/07/1656120conheca-a-melhor-rodovia-do-brasil-com-asfalto-ecologico-e-altos-pedagios.shtml $>$.

FRANCO, R.; HOPENHAYN, M.; LEÓN, A. Crece y cambia la clase media en América Latina: una puesta al día. Revista CEPAL, No. 103. p. 7-26, 2011. Disponível em: <http://www.eclac.cl/publicaciones/xml/7/43077/RVE103Francoetal.pdf>. 
GOODMAN, D. Middle class China: dreams and aspirations. Journal of Chinese Political Science, v. 19, n. 1, p. 49-67, 2014.

GROUT, P. A.; JENKINS, A.; ZALEWSKA, A. Regulatory valuation of public utilities: A case study of the twentieth century. Business History, v. 56, n. 6, p. 936-955, 2014.

G1. Protestos de domingo (13) foram o maior ato político da história do Brasil. 14 March. Disponível em: <http://g1.globo.com/bom-dia-brasil/noticia/2016/03/protestos-de-domingo-13-foram-o-maiorato-politico-da-historia-do-brasil.html>.

(2015) Pelo $5^{o}$ ano, Brasil é último em ranking sobre retorno dos impostos. June $1^{\text {st }}$. Disponível em: <http://g1.globo.com/economia/noticia/2015/06/pelo-5-ano-brasil-e-ultimo-emranking-sobre-retorno-dos-impostos.html >.

HASTINGS, A. et al. 'Managing' the middle classes: urban managers, public services and the response to middle-class capture. Local government studies, v. 40, n. 2, p. 203-223, 2014.

HAUSMANN, R.; PRICHETT, L.; RODRIK, D. Growth accelerations. NBER, working paper 10566. Disponível em: <http://www.hks.harvard.edu/fs/lpritch/Economic\%20Growth\%20-\%20docs/EG\%20$\% 20 \mathrm{Growth} \% 20 \mathrm{vol} /$ growth_accelerations.pdf $>$.

IPEA - Instituto de Pesquisas Econômicas Aplicadas. Sistema de Percepção de Indicadores Sociais: mobilidade urbana. Brasília: IPEA, 2011.

JAVALGI, R. G.; GROSSMAN, D. A. Aspirations and entrepreneurial motivations of middle-class consumers in emerging markets: the case of India. International Business Review, 2016. Disponível em: <http://dx.doi.org/10.1016/j.ibusrev.2015.10.008>.

JOSTEN, S. Middle-class consensus, social capital and the fundamental causes of economic growth and development. Journal of Economic Development, v. 38, n. 1, p. 1-26, 2013.

KIM, J. Y. For the first time, more Latin Americans are middle class than poor. NPQ New Perspectives Quarterly, v. 31, n. 3, p. 42-45, 2014.

KRAVETS, O.; SANDIKCI, O. Competently ordinary: new middle class consumers in the emerging markets. Journal of Marketing, v. 78, p. 125-140, jul. 2014.

LATIN Trade. Can Latin America’s middle class stay afloat? Latin Trade, v. 23, n. 2, p. 25-30, 2015. 
LIMONGI, F. M. P. Governo representativo e democracia: a experiência latino-americana em perspectiva comparada. In: LAGOS, R.; DÁVILA, M.; ZIBETTI, F. W. (Ed.). A América Latina no Mundo: Desenvolvimento Regional e Governança Internacional. São Paulo: EDUSP, 2013.

MATTHEWS, P.; HASTINGS, A. Middle-class political activism and middle-class advantage in relation to public services: a realist synthesis of the evidence base. Social Policy \& Administration, v. 47, n. 1, p. 72-92, 2013.

MILANEZ, B.; SANTOS, R. S. P. Topsy-Turvy Neo-Developmentalism: an analysis of the current Brazilian model of development. Revista de Estudios Sociales, n. 53, p. 12-28, jul/-sep. 2015. Disponível em: <http://dx.doi.org/10.7440/res53.2015.01>.

MILANOVIC, B. Global income inequality by the numbers: in history and now - an overview. Policy Research Working Paper 6259, World Bank, 2012. Disponível em: <http://wwwwds.worldbank.org/servlet/WDSContentServer/WDSP/IB/2012/11/06/000158349_20121106085546/ Rendered/PDF/wps6259.pdf>.

MILLS, C. W. White collar: the American middle class. New York: Oxford University Press, 1966.

NERI, M. A nova classe média: o lado brilhante da base da pirâmide. São Paulo: Saraiva, 2011.

OSBORNE, D.; GAEBLER, T. Reinventing government: how the entrepreneurial spirit is transforming the public sector. Reading, Addison-Wesley, 1992.

O ESTADO de São Paulo. Brasil tem uma das telefonias mais caras do mundo, aponta estudo. 24, nov. 2014. Disponível em: <http://economia.estadao.com.br/noticias/geral,brasil-tem-uma-dastelefonias-mais-caras-do-mundo-aponta-estudo,1597228>.

O GLOBO (2015). Sonhos adiados na Classe C. 16 ago. 2015. Disponível em:http://oglobo.globo.com/economia/sonhos-adiados-na-classe-c-17192732>.

PEW Research Center. Are you in the global middle class? Find out with our income calculator. 16 jul. 2015. Disponível em: <http://www.pewresearch.org/fact-tank/2015/07/16/are-you-in-the-globalmiddle-class-find-out-with-our-income-calculator/>.

Who relies on public transit in the U.S. 7 abr. 2016. Disponível em: <http://www.pewresearch.org/fact-tank/2016/04/07/who-relies-on-public-transit-in-the-u-s/>.

PIKETTY, T. The capital in the 21 st century. Cambridge: Belknap Press of Harvard University Press, 2014. 
SALAMA, P. As classes médias podem dinamizar o crescimento do PIB nas economias emergentes? Estudos Avançados, v. 28, n. 81, p. 7-22, 2014.

SAMSON, I.; KRASIL'NIKOVA, M. The middle class in Russia: an emerging reality or an old myth? Russia Social Science Review, v. 55, n. 5, p. 42-64, 2014.

SÁNCHEZ, M. E.; SENDEROWITSCH, R. The political economy of the middle class in the Dominican Republic: individualization of public goods, lack of institutional trust and weak collective action. Policy Research Working Paper 6049, 2012. Santo Domingo, World Bank.

SCHUCK, P. H. Why government fails so often: and how it can do better. Princeton: Princeton University Press, 2014.

SEEKINGS, J.; NATTRASS, N. Policy, politics and poverty in South Africa. Basingstoke: Palgrave Macmillan, 2015.

SOUZA, A.; LAMOUNIER, B. A classe média brasileira: ambições, valores e projetos de sociedade. Rio de Janeiro: Elsevier, 2010.

STIGLITZ, J. E. Making globalization work. New York: W.W. Norton \& Company, 2006.

TAGUCHI, Y. Civic sense and cleanliness: pedagogy and aesthetics in middle-class Mumbai activism. Contemporary South Asia, v. 21, n. 2, p. 89-101, 2013.

TANNENBERG, M. On the road to better governance: the "Middle Class Particularism" and quality of government. QOG Working Paper Series, n. 9, p. 1-54, 2014.

TEICHMAN, J. The role of the middle class in distributional outcomes: Chile and South Korea. Studies in Comparative International Development, v. 50, n. 1, p. 1-21, 2015.

THALER, R. H.; SUNSTEIN, C. R. Nudge: improving decisions about health, wealth, and happiness. New Haven: Yale University Press, 2008.

THE ECONOMIST. Brazil takes off. 12 nov. 2009. Disponível em: <http://www.economist.com/node/14845197>.
A heavy
load.
31 ago.
2013a.
Disponível
em:

<http://www.economist.com/news/asia/21584374-vietnams-power-grid-under-strain-all-kinds-fusesmay-blow-heavy-load>. 
Has Brazil blown it. 28 set. 2013b. Disponível em:

<http://www.economist.com/news/leaders/21586833-stagnant-economy-bloated-state-and-massprotests-mean-dilma-rousseff-must-change-course-has $>$.

- Bridge over troubled water. 15 nov. 2014 Disponível em: $<$ http://www.economist.com/news/leaders/21632452-weeks-summit-beijing-helped-great-powerrivalry-still-threatens-pacific-bridge $>$.

- Brazil's fall. 2 jan. 2016. Disponível em:

<http://www.economist.com/news/leaders/21684779-disaster-looms-latin-americas-biggesteconomy-brazils-fall>.

THE Wall Street journal. Singapore transport fare hike draws protest. 26 jan. 2014. Disponível em: $<$ http://blogs.wsj.com/indonesiarealtime/2014/01/26/transport-fare-hike-draws-protest-insingapore/>.

THE Washington Post. Why America's middle class is lost. 14 dez. 2014. Disponível em: <http://www.washingtonpost.com/sf/business/2014/12/12/why-americas-middle-class-is-lost/>.

. Why your middle-class salary is better than you might think. 15 jun. 2015. Disponível em: <https://www.washingtonpost.com/news/wonk/wp/2015/06/15/the-big-problem-with-one-of-themost-commonly-cited-numbers-about-the-economy/>.

TIME. Huge antigovernment protests in Malaysia continue for a second day. 30 aug. 2015. Disponível em: <http://time.com/4016193/malaysia-protests-bersih-najib-razak/>.

TORCHE, F.; LOPEZ-CALVA, Luis F. Stability and vulnerability of the Latin American Middle Class. Oxford Development Studies, v. 41. n. 4, p. 409-435, 2013.

UNGER, R. Por que votar em Dilma. 13 out. 2014. Disponível em: <http://www1.folha.uol.com.br/opiniao/2014/10/1530909-roberto-mangabeira-unger-por-que-votarem-dilma.shtml>.

UOL. Classe média tem que voltar para a escola pública, defende especialista. Mai. 2014. Disponível em: $\quad<$ http://educacao.uol.com.br/noticias/2014/05/29/classe-media-tem-que-voltar-para-a-escolapublica-defende-especialista.htm>.

U.S. Department of Labor. Consumer Expenditures Midyear Update - July 2013 through June 2014 average. Bureau of Labor Statistics. 2 abr. 2015. Disponível em: <http://www.bls.gov/news.release/pdf/cesmy.pdf>. 
VASCONCELLOS, E. A. The making of the middle-class city: transportation policy in Sao Paulo. Environ Plan A, v. 29, n. 2, p. 293-310, 1997.

VEJA. Que nota os brasileiros dão para o transporte coletivo? Um app israelense responde. 23 jan. 2016. Disponível em: <http://veja.abril.com.br/noticia/vida-digital/que-nota-os-brasileiros-dao-parao-transporte-coletivo-um-app-israelense-responde>.

WORLD Bank. Internet users (per 100 people). 2016. Disponível em: <http://data.worldbank.org/indicator/IT.NET.USER.P2?locations=BR\&year_low_desc=true>.

WORLD Economic Forum. The Global Competitiveness Report 2015-2016. Genève: World Economic Forum, 2016.

ZINGALES, L. Um capitalismo para o povo: reencontrando a chave da prosperidade americana. São Paulo: Bei Comunicações, 2016. 
